\title{
Troubling the Victim/Trafficker Dichotomy in Efforts to Combat Human Trafficking: The Unintended Consequences of Moralizing Labor Migration
}

\author{
Kay Warren \\ Brown, Kay_warren@brown.edu
}

Follow this and additional works at: https://www.repository.law.indiana.edu/ijgls

Part of the Human Rights Law Commons, International Law Commons, and the Labor and Employment Law Commons

\section{Recommended Citation}

Warren, Kay (2012) "Troubling the Victim/Trafficker Dichotomy in Efforts to Combat Human Trafficking: The Unintended Consequences of Moralizing Labor Migration," Indiana Journal of Global Legal Studies: Vol. 19 : Iss. 1 , Article 4.

Available at: https://www.repository.law.indiana.edu/ijgls/vol19/iss1/4

This Symposium is brought to you for free and open access by the Law School Journals at Digital Repository @ Maurer Law. It has been accepted for inclusion in Indiana Journal of Global Legal Studies by an authorized editor of Digital Repository @ Maurer Law. For more information, please contact rvaughan@indiana.edu. 


\title{
Troubling the Victim/Trafficker Dichotomy in Efforts to Combat Human Trafficking: The Unintended Consequences of Moralizing Labor Migration
}

\author{
KAY B. WARREN ${ }^{\star}$
}

\begin{abstract}
This analysis examines the violent predator/innocent victim paradigm employed by many governmental and nongovernmental organizations active in monitoring and combating transnational human trafficking. One common treatment of the issue moralizes victims as innocent women and children who have been deceived and coerced into exploitative sex work; another constructs human trafficking as modern day slavery which takes a variety of forms and requires foreign intervention to organize rescues and redemption. Both views see human trafficking, most especially sex trafficking, as an exceptional crime with distinct predators and victims and cultivate moral outrage as a strategic tool to combat coerced labor. This essay draws on my ethnographic interviews in Colombia from 2007-2011 and analyzes trial evidence from prosecutions of human traffickers in Colombian courts to interrogate the polarized predator/victim discourse. In practice, many Colombian women reject the victim label for their overseas work. Court cases document alternative renderings of women's subjectivity and portray organized crime as a transnational mix of licit and illicit businesses with wider social norms and divisions of labor. In practice, Colombian legal cases reveal women accepting a variety of jobs in trafficking
\end{abstract}

* Kay B. Warren is the Charles C. Tillinghast, Jr. '32 Professor of International Studies and Professor of Anthropology at Brown University where she directs the Pembroke Center. This analysis explores lines of argument that are featured in the book Warren is writing on human trafficking from Colombia to East Asia. She is the author of Indigenous Movements and Their Critics and editor, with David Leheny, of Japanese Aid and the Construction of Global Development: Inescapable Solutions, among many other books. My thanks to the organizers of the Maurer School of Law Globalization and Migration Symposium at Indiana University on March 20, 2011. It was a pleasure to test my initial ideas in such a lively and collegial setting.

Indiana Journal of Global Legal Studies Vol. 19 \#1 (Winter 2012)

(C) Indiana University Maurer School of Law 
organizations after they have paid off their initial debts to the organization. What is the significance of these clashing understandings? How do these organizations operate in plain sight as businesses and employers while the scope of their social relations and work situations are reduced in the realm of antitrafficking activism to the singular predator/victim paradigm?

My ongoing research on transnational human trafficking focuses on antitrafficking efforts and explores how international norms to combat human trafficking, global monitoring frameworks, antitrafficking media, and activist groups have constructed a moral economy of gendered violence and transnational crime with a genealogy of discourses. ${ }^{1}$ In this social imaginary, innocent young women and children (most often minors) ${ }^{2}$ are captured and sexually exploited by sociopaths and predators, gendered male, who force them into prostitution far from home. ${ }^{3}$ Suicide, escape to a safe haven, or rescue and redemption are portrayed as the only exits from this terrifying situation. This morally driven and individualized construction informs the work of many international and national nongovernmental

1. For the international norms that were developed to criminalize human trafficking, see generally: United Nations Convention Against Transnational Organized Crime, G.A. Res. 55/25, Annex I, U.N. Doc. A/RES/55/25 (Nov. 15, 2000); Protocol to Prevent, Suppress and Punish Trafficking in Persons, Especially Women and Children, G.A. Res. 55/25, Annex II, U.N. Doc. A/RES/55/25 (Nov. 15, 2000); and Protocol Against the Smuggling of Migrants by Land, Sea and Air, G.A. Res. 55/25, Annex III, U.N. Doc. A/RES/55/25 (Nov. 15, 2000). For analyses of the making of these norms at the United Nations Office on Drugs and Crime headquarters in Vienna, see Kay B. Warren, The 2000 UN Human Trafficking Protocol: Rights, Enforcement, Vulnerabilities, in THE PRACTICE OF HUMAN RightS: TRACKING LAW BeTWEen THE Global AND THE Local 242 (Mark Goodale \& Sally Engle Merry eds., 2007); and, on norm making appropriated to local levels, see Kay B. Warren, Trafficking in Persons: A Multi-Sited View of International Norms and Local Responses, in JAPANESE AID AND THE CONSTRUCTION OF GLOBAL DEVELOPMENT (David Leheny and Kay B. Warren eds., 2010); see generally SALLY ENGLE MERRY, HUMAN RIGHTS AND GENDER VIOLENCE: TRANSLATING INTERNATIONAL LAW INTO LOCAL JUSTICE (2006).

2. According to international norms, adults are eighteen years old. The wide use of "children" in antitrafficking literature takes advantage of the imprecision of this term and its connotations of dependence and sexual innocence. The issue of consent, something that is only relevant at adulthood, is crucial in international norms. Colombian professionals increasingly distinguish between children and adolescents in their writings.

3. Critics of prostitution, most notably Kathleen Barry, adopted a wide ranging abolitionist language in the mid-1970s. She entitled her 1979 manifesto Female Sexual Slavery. KATHLEEN BARRY, Female Sexual Slavery (1979). For her, this term describes all situations where women or girls are subject to force, cannot change their immediate conditions of existence, and are thereby subject to sexual violence and exploitation at home or as prostitutes. See generally id. This is a foundational violence, above all others, that needs to be abolished as slavery was. 
organizations (NGOs), including organizations like the International Justice Mission that specialize in "rescues" and NGOs and government offices that work with repatriated "victims." This framing has been compelling for religious and secular groups in the United States. It is a dominant discourse in the U.S. government, especially in the Department of State, where the Trafficking in Persons Office (G-TIP) organizes antitrafficking efforts and publishes the Trafficking in Persons Report, an annual country-by-country accounting of international trends in trafficking. It also widely circulates in documentaries, news, and charitable solicitations in print and digital media that target the general public. ${ }^{5}$

The result has been a widely circulating moralization of human trafficking as an exceptional form of transnational, sexualized violence, one that denies its gendered victims any sort of agency or voice in the

4. The "victim" paradigm has a long and complex contemporary lineage, starting with abolitionists who, in this context, focus on prostitution and human trafficking as a unitary issue. See generally, e.g., BARRY, supra note 3; KATHLEen BARRY, Prostitution OF Sexuality: The Global Exploitation of Women (1995); Prostitution, TrafFicking, and Traumatic Stress (Melissa Farley ed., 2003); Sheila JeFrReYs, The IDEA of Prostitution (1997); Janice G. Raymond, Coal. Against Trafficking in Women, GUIDE to THE NEW UN TRAFFICKING PROTOCOL (2001). For a contrasting worker rights framing, see ANN D. Jordan, InT'L Human Rights LaW GrP., The ANNOTATED GUIDE to THE COMPLETE UN TRAFFICKING PROTOCOL (2002). Contemporary constructions of victims of human trafficking often use the language of "modern day slavery" that has been developed by a new generation of activists. See generally, e.g., KEVIN BALES, ENDING Slavery: How We Free Today's SLAVES (2007) [hereinafter ENDiNG SLAVERY]; KeVIN BALES, UNDERSTANDING GLOBAL SLAVERY: A READER (2005) [hereinafter UNDERSTANDING Global Slavery]; Jim HanCock, The INT'L Justice Mission, The Justice Mission: A VIDEO-ENHANCED CURRICULUM REFLECTING THE HEART OF GOD FOR THE OPPRESSED OF THE WORLD (2002). See also, ENSLAVED: TRUE STORIES OF MODERN DAY SLAVERY (Jesse Sage \& Liora Kasten eds., 2006), a compilation by the directors of the American AntiSlavery Group. The language used in these books has been adopted for a wider ranging agenda of activism, of which human trafficking is a central component.

5. On the production and politics of these rankings, see generally Kay B. Warren, The Illusiveriess of Counting "Victims" and the Concreteness of Ranking Countries: The Practice of Combating Human Trafficking from Columbia to Japan, in SEX, DRUGS, AND BODY CounTS: THE POLITICS OF NUMBERS IN GlOBAL CRIME AND Conflict 110 (Peter Andreas \& Kelly M. Greenhill eds., 2010); David A. Feingold, Trafficking in Numbers: The Social Construction of Human Trafficking Data, in SEX, DrugS, AND Body CounTs: ThE Politics of Numbers in Global CRIMe and Conflict 46 (Peter Andreas \& Kelly M. Greenhill eds., 2010); ANTHONY M. DESTEFANo, THE WAR ON HuMAN TrafFICKING: U.S. POLICY ASSESSED (2008). For wider considerations of monitoring systems, see generally, Sally Engle Merry, Measuring the World: Indicators, Human Rights, and Global Governance, 52 CURRENT ANTHROPOLOGY 83 (2011). In fact, the U.S. Government Accountability Office (GAO) produced an important critique of the TIP ranking that was read with great interest. See U.S. Gov'T ACCOUNTABILITY OFFICE, GA0-06-825, HUMAN Trafficking: BetTer Data, Strategy, aNd REPorting NeEded to EnHance U.S. ANTTTRAFFICKING EFFORTS ABROAD (2006). 
matter. For some antitrafficking movements, this labeling has the effect of isolating "victims" of human trafficking from other forms of migrant labor that involve coercive recruitment and exploitative control through debt bondage. ${ }^{6}$ It rejects the idea that these workers may well have other understandings of their work, alternative definitions of how jobs far from home might serve their family's financial goals, and other positions in the organizations they decide to work for. The stigma associated with sex work reinforces this exceptionalism. ${ }^{7}$ In research and educational circles, the earlier abolitionist fascination with exceptionalist constructions of "prostitution" and "trafficking" risked misconstruing sexual crimes as a unique signature of human trafficking and further marginalized other forms of labor migration for many audiences-for students who are exploring moral and ethical issues around the world and for public awareness as human rights activists challenge widespread indifference to poverty at home and abroad. More recently, however, international donors have redirected their funding to combat the exploitation of minors in brothels, armed forces, adoption, begging, mining, carpet weaving, the production of chocolate, and other forms of domestic service servitude that involve violent control.

Critics of the TIP reports lobbied in Washington, DC after the annual release of new reports for the broader perspectives that included labor issues besides sex trafficking. The net effect of pressure from the workers' rights left, the antislavery movement, and religious right has been to transform the scope and balance of issues monitored in the TIP reports. The reframing of human trafficking as many kinds of slavery has become hegemonic on the international level, an ascendant form of neoabolitionism with a new activist agenda in which heterogeneous issues can be combined in the identical framework of strategies to achieve justice by freeing slaves. To a great extent, however, this international paradigm reproduces the grammar of evil predators and

6. Debt bondage generally saddles workers with substantial debts, generally explained to them as advances to cover the cost of their transportation, food and housing, travel documents, clothing, medicines, and other expenses. In many parts of the world, this is a very old practice used to control and exploit migratory workers in agricultural work, mining, slaughter houses, manufacturing, and domestic service in the informal and formal economies. In this scheme, workers are not free to change jobs or return home until their often highly inflated personal debt is cancelled. Workers may be fined for infractions or not filling work quotas; they may be sold to other businesses. One can see how these debts can be easily manipulated and the work extremely coercive as it treats humans as commodities. This form of coercion becomes an important issue across a wide range of abolitionist and workers' rights perspectives on trafficking. See generally BALES, ENDING SLAVERY, supra note 4; BALES, UNDERSTANDING GLOBAL SLAVERY, supra note 4.

7. On stigma, see Erving Goffman's classic work, ERVING GOFFMAN, STIGMA: NOTES ON THE MANAGEMENT OF SPOILED IDENTITY (1963), which calls for a critical reading for the ways that his analysis reproduces the very problem it explores. 
innocent victims with some heroic local figures and critical support from the West to rescue slaves. Both varieties of abolitionism cultivate moral outrage as a tool to mobilize wider publics in support of institutions to combat slavery as violent abuse and exploitation, with onerous debts, no freedom of movement, and extreme exploitation of young children and minors.

So far this analysis has discussed how particular kinds of victims, interventions, and systems for the global monitoring of violent crime are produced by this genealogy of discourses. One alternative to the deeply moralized quest to combat human trafficking is to take a fresh look at criminal organizations as businesses that operate and profit transnationally from highly flexible social formations that link labor supplies with commercial demands in different parts of the world. ${ }^{8}$

My ongoing research ${ }^{9}$ deals with the human trafficking of adult women from Colombia to Japan, Hong Kong, and Singapore for the sex entertainment industry. ${ }^{10}$ It traces the process through which

8. For research that follows this approach, see generally: DENISE BRENNAN, WHAT's Love Got to Do With It? TRansnational DESIRES AND SEX TOURISM IN The Dominican REPUBLIC (2004); GLOBAL SEX WORKERS: RIGHTS, RESISTANCE, AND REDEFINITION (Kamala Kempadoo \& Jo Doezema eds., 1998); TRAFFicking AND ProstTtution Reconsidered: New Perspectives on Migration, Sex Work, and Human Rights (Kamala Kempadoo et al. eds., 2005). More generally, on the issue of human trafficking as business, see louise Shelley, Human Trafficking: A Global Perspective (2010); Kathryn FARR, SEX TRAFFicking: THE Global MARKET IN WOMEN AND CHILDREN (2005); TrafFicking AND the GLOBAL SEX INDUSTRY (Karen Beeks \& Delila Amir eds., 2006).

9. My ethnographic and historical research behind this line of argumentation includes ethnographic work from 2003-2006 in Japan on efforts to combat human trafficking by activist officials at the Colombian and U.S. embassies, Japanese feminist lawyers, and research groups on human trafficking. I worked with representatives of Japanese government agencies including the National Police Association and Ministry of Foreign Affairs. My research followed regional and international NGOs as they pressured the Japanese government to come into compliance with international antitrafficking norms. From 2007-09, my research shifted to Colombia where I have worked with antitrafficking NGOs, the United Nations Office on Drugs and Crime, International Organization for Migration, a variety of Colombian government offices (including Das-Interpol and the Attorney General's office), and legal scholars working at major universities. My research turned to court records of the prosecution of human traffickers in Colombia. Since 2009, my work has focused on analyzing court records and interviews with Colombian judges, prosecutors, defense attorneys, and witnesses involved in antitrafficking prosecutions. This multisited research has been supported by grants from the Social Science Research Council and Abe Foundation (Japan), a Senior Research Fulbright Fellowship, and the Watson Institute and Brown University.

10. For a comprehensive International Labour Organization report on the Japanese sex entertainment industry, just as international antitrafficking pressures and critiques of Japan's indifference were growing, see MITSUKO HORIUCHI \& ROGER PLANT, INT'L LABOUR ORG., HUMAN TRAFFICKING FOR SEXUAL EXPLOITATION IN JAPAN (2004). For early coverage of the Colombia-Japan trade, see Fanny Polania Molina, Japan, the Mecca for Trafficking in 
international norms, promulgated through the 2000 United Nations Palermo Accords, were appropriated by Colombian activist lawyers to target the new crime of human trafficking for prosecution in the national criminal justice system. Government officials were especially concerned with how traffickers recruit Colombian labor for jobs in other parts of the world.

Some findings of my research are counterintuitive given the reigning understanding of human trafficking. ${ }^{11}$ First, this anthropological framing directs greater attention to women's subjectivity. Women returning from East Asia to Colombia do not necessarily identify as "victims." This issue has been a common theme in my interviews with grassroots NGOs, courtroom prosecutors, and former migrant laborers who want to distance themselves from their past. Many of these women see themselves as people who made unfortunate job decisions that resulted in their having to work in exploitative and dangerous conditions with poor pay, both chronic issues in their work lives as a whole whether or not they leave their home communities. ${ }^{12}$ We know much less about Colombian men who have returned from similar work routes. Some young men, for instance, are recruited by these same networks to work in notorious gangs that specialized in home robberies in Tokyo; they occasionally appear in the Japanese sex entertainment industry or work in Colombian organized crime networks that interface with members of Japanese and Eastern European organized crime.

Colombian Women, LIBERTADLATINA.ORG (1999), http://www.libertadlatina.org/
paper30ColombiaJapan.pdf.

11. The issue of labor migration has been of growing interest to Colombian policymakers and NGOs. See generally, e.g., ElVIa VARGas TrUJILlo, CaRmEN EliSA Flóres \& laura María Mendoza Simonds, Trata de Personas en Colombia: Una aproximación a la Magnitud y Compensión del Problema (2011); María López Montaño, Familas Transnacionales: Oportunidad Y Cambio EN Contexto MigRaTORIO (2009); WILLIAM MEJÍA ET AL., OBSERVATORIO COLOMBIANO DE MIGRACIONES, RESULTADOS GENERALES DE LA ENCUESTA NACIONAL DE MIGRACIONES INTERNACIONALES Y REMESAS 2008-2009 (2009); Thomas Barbat, Remesas, pobreza y trabajo. Estudio sobre el barrio Cuba. Pereira-Colombia, 1 CuADERNos MIGRANTES 1 (2008). On human trafficking with diverse forms of work, see generally UNIVERSIDAD NACIONAL DE COLOMBIA \& UNITED NATIONS OFFICE ON DRUGS AND CRIME, ESTUdIO NACIONAL EXPLORATORIO DESCRIPTIVO

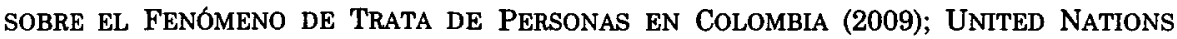
OfFice on DRUgS and CRIMe, Memorias. Conferencla Regional Trata de Personas: TEORÍA Y PRÁCTICA DE LA COOPERACIÓN REGIONAL E INTERNACIONAL (2003); FuNDACIÓN Esperanza, Trata de PERSonas y Desplazamiento Forzado (2004); Global Alliance against Trafficking Women, Manual Derechos Humanos y Trata de Personas, Alianza Global Contra la Trata de MuJeres (2001).

12. See generally Warren, supra note 5 . 
Second, it has been a continuing puzzle to social service organizations working to combat trafficking and repatriate workers to their homeland that relatively few women return to Colombia from their time working overseas in Japan, East Asia, or elsewhere. ${ }^{13}$ There is no evidence that women are being targeted and killed or are dying of diseases like HIV/AIDS in large numbers. Where do these women go and what kinds of work do they end up doing? Do they, in fact, find better work or better working conditions internationally than their prospects in Colombia? Very little reliable research has been done on these issues.

Third, in Colombia, there is the puzzle of missing social movements focusing on abuse by traffickers. In the early and mid-2000s there was very successful activism on the part of Colombian women lawyers in NGOs and legal reform to criminalize traffickers rather than their labor recruits who were intercepted at international airports with forged passports and visas given them by those in charge of the relocation process. Nevertheless, there has been no significant collective mobilization of Colombian women as "transnational sex workers" or "trafficking survivors," and no activist surge to press for expanded rights and access to services as "formerly trafficked women."14

13. See id. (discussing the politics of numbers and the difficulties of counting people who have been trafficked).

14. This lack of organizing contrasts with a variety of smaller mobilizations of local groups of sex workers pressing for better working conditions or regional movements critical of U.S. military bases in other parts of the world. Among the wider and powerful international coalitions of antitrafficking organizations that pressure for antitrafficking reforms, there are many organizations of professionals and middle-class activists that do not involve migrant workers as members or in leadership roles. These national and international groups work through international conferences and meetings to pressure governments to reform legal systems, disestablish entertainment visas that legitimize mass state to state sex trafficking, and provide basic services to migrant women when they are arrested in foreign countries. For more critical perspectives, see GLOBAL SEX WORKERS: RIGHTS, RESISTANCE, AND REDEFINITION, supra note 8; TRAFFICKING AND Prostitution Reconsidered: NeW Perspectives on Migration, SeX Work, AND HUMAN RIGHTS, supra note 8 (these publications include situations where workers have organized or have become parts of wider social movements on particular issues). In Colombia, there has been a long tradition of activist jurists, legal scholars, and heads of national NGOs, many of them women. There have also been significant projects by the Government concerned with sex worker rights, health, exclusion from civil society, and abuse by the authorities. Some efforts that received financial support from international donors, such as the French, have included sex workers as leaders in social activism and self-governance projected in zonas de tolerancia those who "work in prostitution" (ejercen la prostitución)-a wording that avoids the label "prostitute" which is seen as stigmatizing-are legally free from institutionalized police harassment and are full members of community life who are welcome to run for public office and be active in community affairs. 
Fourth, women who return home through formal channels, such as the Colombian consulate in Tokyo, receive health screenings, temporary housing, and short-term counseling from the Colombian branch of the International Organization for Migration (IOM-Colombia), a major international NGO with a long history of activism on international migration issues. Some women turn to local service providers in their home regions for additional short-term support. But the staff of these organizations agree that return migrants rapidly disappear from local social centers designed to help women address problems in their lives, pursue continuing education if they wish, and access to multifaceted support for local sex workers. ${ }^{15}$ Return migrants anticipate being stigmatized in their home communities, where they and their families face threats and punishment by criminal networks for any unpaid debts. Their immediate families may not welcome them back, especially if they feel betrayed by daughters who left children with their grandmothers yet failed to send remittance earnings in return. It is said by NGO workers that families assume the worst, that their daughters recklessly spent their earnings in Japan living the high life on the alluring streets of Ginza. In so doing, they violated the moral economy of the family's collective dreams for economic improvement that justified the risk of transnational migration to a mythical distant country in the first place. Families may simply be unaware that labor migrants face highly inflated debts of up to $\$ 40,000$ (putatively for travel documents, plane tickets and other travel expenses, someone to accompany travelers and to provide tactical assistance getting through customs with the right answers to agent's questions and self-presentations that reflect the data in forged documents, and others arranging their transfer to their new work site). These charges are discounted from their earnings until the advance is repaid. Migrant workers face relentless pressure to pay debts, and threats and beatings if they do not fill their work quotas. It appears from court cases that women in better work situations abroad are able to pay off debts in a matter of months.

Narratives I collected in Japan in 2004-2007 highlighted continual attempts by women labor migrants to jockey for jobs with better working conditions, even if it involved assuming more debt to do so. These women saw themselves as active agents in difficult circumstances who networked with other women or sympathetic men they met to improve their situations or change the kind of work they were doing. Alternative work situations that came up in my interviews ranged from jobs in entertainment businesses with better working conditions to

15. These findings are from my interviews of local NGOs, their social workers, and discussions with former migrants in 2009 and 2010. I have decided to protect the confidentiality of these organizations. 
factory assembly work for small subcontracting businesses, or serving as a nanny for well-off families in criminal networks.

My current work in the Colombian court system, analyzing court records and interviewing judges, prosecutors, defense attorneys, and investigators, add new dimensions to these findings. ${ }^{16}$ In these court cases, which span the relocation of Colombian trafficking networks from Japan to Singapore and Hong Kong and the importance of regional Latin American networks from Colombia to Panama and Ecuador-very different social formations appear. ${ }^{17}$ The morally derived absolute distinction between traffickers and their victims is deconstructed by the lines of evidence presented in trial proceedings. ${ }^{18}$ These trials also signal the impunity that the top bosses of trafficking networks enjoy. They live abroad, beyond the reach of the law. Prosecutions focus on lower levels of the networks that are directly connected to Colombia.

A careful reading of these cases reveals that Colombian trafficking networks operate as flexible transnational kinship organizations of several sorts. ${ }^{19}$ One common family mode is based on domestic partnerships. In smaller organizations, for example, the boss may bring a new female domestic partner on board as a manager to oversee the supervisors involved in the scheduling and collecting payments from the workers in the business. Managers and supervisors are referred to in Spanish as manillas. In some networks, case evidence shows domestic partnerships routinely fracturing as partners find new lovers, with the

16. For an insightful analysis of Colombian government institutions working to combat human trafficking and the challenge of harmonizing the data they produce, see generally, MoniCa HuRTADO, Dimensiones de la TRATA DE PERSONAS EN Colombla (2006).

17. In this Article, I have chosen not to identify the legal authorities or other parties involved in the cases by name. Rather, I refer to individuals by their roles in the cases. In Colombia, judges, prosecutors, investigators, defense attorneys, and other officials work under overwhelming pressure from the constant threats they receive for their work on human trafficking and human rights abuses. I handle this issue in the same way for the accused, witnesses, and others mentioned in court records. The records I worked with in Colombia are expedientes (trial proceedings) of cases that have been completed. They are stored at the National Attorney General's office, regional offices, and organizations such as UNODC.

18. A primary mode of evidence developed by antitrafficking investigators to map organized crime networks is information acquired from major wire transfer companies that are used by organized crime to pay their employees in different parts of the world. This is a good example of the way illicit businesses incorporate conventional legal services in their operations. See generally, CAROLYN NORDSTROM, SHADOWS OF WAR: VIOLENCE, Power, AND INTERNATIONAL PROFITEERING IN THE TWENTy-FirST CENTURY (2004), on the uses of travel and banking to facilitate transnational commerce.

19. Descriptions of three generational networks appear in C-9920, 2007, MedellínHong Kong (Colom.) and C-1456, 2006, Manizales, Buenaventura-Hong Kong/Singapor (Colom.). Networks composed of extended families with neighboring residences appear in C-217, 2002, Ibagué-Japón (Colom.) and C-1108, 2007, Pereira-Panamá (Colom.). 
larger network able to maintain the solidarity of the group as a whole. Working effectively with former partners is a job requirement, a local cultural norm. Other family networks center on mother-daughter dyads, including former sex workers who have gained promotions to higher positions as supervisors and then decided to recruit their daughters into the business. In a permutation of both modes, the social organization of some networks combines domestic partners with mother-daughter dyads in a way that produces three generation collaborations of women. One young woman gained mobility by living with her boss as a couple and working alongside him in his Hong Kong business. Her mother retained a supervisory position in the group, and her grandmother watched over her granddaughter's children in Colombia. Still, other networks are built of clusters of extended families each with their own home-which in some Colombian cases wind up accusing each other of crimes. Clearly, images of trafficking networks as family businesses complicate the vision of solo traffickers and victims in favor of the family basis common to other kinds of organized crime.

From interviews and court cases in Pereira and Medellín, it is clear that women often work as labor recruiters in Colombia. Mothers work with their daughters, sisters, or other close relatives in the coffeegrowing region of the country. ${ }^{20}$ It is clear that men do this work as well. ${ }^{21}$ This dual gendering of human trafficking networks contrasts with the image of the predatory male stranger common in antitrafficking media. In court proceedings, the criminal justice system generates a distinctive set of representations-including kinship diagrams that judges produce as part of their reading practices as they review cases-that represent trafficking organizations as illicit businesses that operate transnationally across formal and grey economies and offer mobility to some of their workers. The distinction between sex worker and supervisor turns out to be a relatively fluid one, and individual women may pass back and forth between these statuses. In mother-daughter dyads, some daughters continue to do sex work, while some older women tend to find positions as full-time supervisors. Some supervisors share housing and meals with their workers; in other networks, they live apart. It is easy to see how higher level bosses would encourage kinship and residential arrangements that promote discipline and offer different sorts of flexibility at the same time as they accommodate transnational labor recruitment and the care of

20. The organization of recruiting networks is illustrated in C-1108, 2007, PereiraPanamá (Colom.); C-3921, 2006, Barranquilla-Hong Kong (Colom.); C-1458, 2006, Manizales, Pereira, Buenaventura-Hong Kong, Singapor (Colom.); C-3984, 2006, PereiraHong Kong (Colom.).

21. See C-4084/2314, 2000, Pereira (Colom.); C-3984, supra note 20. 
dependents. From the cases I read and interview questions I pursued with court officials, it is evident that kinship is a multidimensional idiom that promotes network fluidity. For instance, U.S. pressure and monitoring of Japanese antitrafficking strategies in the mid 2000s and Japanese enhanced airport enforcement and highly publicized brothel busts put heightened pressure on networks operating the ColombiaJapan route. The result was a switch in intermediary routes and Hong Kong and Singapore as final destinations and an emphasis on delivering women to clients as an alternative to operating brothels. As a result, more prosecutions involve these new destinations.

The judges and prosecutors explained additional factors in their choice of cases they gave me for my research for this study. Preference was given to cases in which the verdicts, sentencing, and their appeals were completed. Officials shared cases that represented different scenarios in the investigation and prosecution of human trafficking in the Colombian system. They selected cases that were instructive from a criminal justice perspective and posed unexpected or ironic challenges. The antitrafficking judges and prosecutors were intrigued by the evidence their investigators found on the social relations that mediated human trafficking networks. One of the reasons for this interest is that the dominant media portrayals of international trafficking do not routinely deal with the wider kinship relations basic to these organizations. On the whole, the producers of antitrafficking coverage focus viewers' attention on dramatic brothel raids and the need to motivate the police to do the same, echoing policing patterns rather than exploring the functioning of illicit migration networks.

Do court records have anything to say about whether these women workers ever return home to Colombia? In fact, cases include examples of managers and supervisors who carefully calculate the escalating risk of arrest during "antiprostitution" campaigns and intensified police raids abroad. In other instances, as my interviews with jurists document, women just want a break, to come back home to live in their own country for a while. There are examples of labor migrants working in these networks who are able to legally return to Colombia by passing as simple sex workers who have just escaped from their captors and are seeking consulate help to get home. This, of course, is gaming the system, that is, using the system against itself. ${ }^{22}$ Or they can reenter the country illicitly. ${ }^{23}$

Moreover, the ebb and flow of Colombian migrant workers caught up in criminal prosecutions, which often go on for years, has its own

22. The judges I interviewed were very interested in how individuals attempted to take advantage of the system; the term "gaming," however, is my usage.

23. This description comes from interviews and discussions I have had with court authorities in 2010-2011. 
logic. Faced with having to make a living as antitrafficking trials go on, some of the principals involved in these cases travel elsewhere in Latin America to countries like Panama to seek more lucrative work when jobs fail to materialize closer to the trial venues. To do so, they are required to petition the court for the authorization international work visas. Case records show migrant workers asking for visas as dancers or sex workers. Latin American labor migration becomes an option for higher earnings for women caught in long urban trials far from social capital they might have in their home regions. Petitioners for these visas may be released on their own recognizance during the trial proceedings, or they may be people who have accused Colombian traffickers of crimes against close relatives and, thus, are required to be available to the court. Traveling to other parts of Latin America, where migrants can operate in their own language, can be convenient and profitable. But it would seem marginally worth the trouble when there is intense pressure to return to their trials.

Part of the allure of leaving Colombia in these situations may well be that it is a totally legitimate delaying tactic. This is another way they can game the system. Judges and prosecutors try to put pressure on transnational workers to return to Colombia when their absence slows the process of convening hearings; however, the visa regulatory system, which is not controlled by the judiciary, makes these petitions selfdefeating for the court. Repeated and apparently fruitless attempts to contact participants involved in trials is a chronic frustration prosecutors and the judiciary simply have to endure. Ironically, as investigators pointed out to me in an interview on one notable case, both the accuser and the accused petitioned the court to let them work in Panama while the trial was in an inactive phase. Their paths never crossed only because of travel delays for one of the women. ${ }^{24}$

\section{CONCLUSIONS}

In practice, the clashing perspectives of human trafficking explored in this essay reveal a complex world of business interests and the reasons why it is so difficult to convict human traffickers on the basis of victim testimony. The trafficker/victim dichotomy is a discursive move to harness the power of moralizing, that is both gendered and generational, to produce innocent victims for wider publics, human rights activism, service providers, and the state. This strategy concomitantly creates the conditions of possibility for thriving

24. The details of this example come from interviews with court officials in 2011. The court proceedings in question come from C-3984, supra note 20. 
businesses, especially NGOs that fundraise from the general public and provide social services as subcontractors in the fields of human rights and justice. ${ }^{25}$ One problematic effect (even with the Department of State TIP Office's "protection, prosecution, prevention" paradigm of interventions) is that migrant women's subjectivity risks being reduced to the logic of coercion and violence, without meaningful agency or room for maneuver.

However, in practice there is an interesting twist to this image of helplessness. In this paradigm, migrant women need the help of others to escape the "slavery" of their traffickers, but also in the current world of neoliberal values and social policy they are expected to be selfdirected individuals responsible for themselves. The tension between helplessness and responsibility frequently came up in public discussion when I was in Japan. It seemed to feed the widespread public and official indifference to the fate of Colombian women who were arrested and sometimes jailed for visa overstaying in Japan for visits in 20042006. Their outlier status and apparent abandonment by the recruiting and transit networks were further reinforced when, upon entering the country, they were jailed as foreign criminals without legal papers, rights, or status as legal victims of human trafficking. Their position as non-Japanese foreigners (gaijin) who, by definition, cannot be part of the moral community or competent in Japanese culture or language only reinforced this marginal status. Migrant women at fault in this complex web of meanings raised the troubling notion of contingent human rights. By implication, these isolated and stigmatized women risked occupying a space at the extreme margins, without a voice or legal advocates, where they were routinely treated as not fully humandenied ontological recognition as part of the social and undeserving of the same "universal" rights that others enjoy by definition. ${ }^{26}$

The anthropological interrogation of the human trafficker and innocent victim in Colombian court cases reveals much more than evil predators. Court cases and my interview data have allowed this investigation to trace the operation of transnational illicit businesses from Colombia to Japan and beyond to Hong Kong and Singapore. In the process, one can see how jobs in these organizations offer some women and their relatives upward mobility and family life as migrant labor in the sex entertainment sector. Workers are integrated into small- and medium-sized enterprises through kinship networks-

25. This important issue deserves further consideration; however, it is beyond the scope of this Article.

26. Their isolated, liminal position, being lost in a system without language which denies their humanity, echoes Begoña Aretxaga's discussion of Giorgio Agamben in Begoña AretXaga, States of Terror: Begoña ARétXagA's Essays 127-46 (2005). 
domestic partnerships, sibling relations, extended families, and transnational kinship networks-and in the process gain a variety of interlocking positions such as supervisors, managers, recruiters, and childcare workers in the wider structure. ${ }^{27}$

This analysis also reveals some of the challenges and frustrations that Colombian authorities face in prosecuting these illicit businesses. Court proceedings routinely shift from a victim-focused to businessfocused questioning to provide additional evidence against members of criminal networks. This is due to the difficulty of producing "good" victims as witnesses who make the case by offering testimony that meets the strict legal requirements under Colombian law for the charge of "human trafficking" in the initial phase of court proceedings. In court hearings, women who occupy the victim slot at the beginning of trials often give unruly testimony; they tell of earlier trips abroad, of accepting job offers that involved sex work, and of keeping their passports and making money rather than being held against their will, being deprived of their legal papers, and economically exploited. Or, they just disappear from the courtroom in short order. These responses can be read literally as reflective of their experiences, as a result of their personal desire to trouble the legal system, or as the result of coaching from a variety of legal sources (lawyers, prosecutors, family members) and extra-legal sources (including enforcers from organized crime sent to hearings to intimidate by their very presence). Witness intimidation is part of the courtroom environment. ${ }^{28}$ Regional antitrafficking courts are located in cities such as Pereira and Medellín which have long been notorious centers of organized crime. There is no space distinctly outside the influence of organized crime and the illicit economy in these situations. When early witnesses fail to perform as hoped, the prosecution is forced to abandon charges of human trafficking in favor of

27. There are interesting lessons from these findings on kinship and migrant labor for impoverished women in Colombia. Extrapolating from these court proceedings, for instance, one could imagine a provocative range of interventions to improve women's economic situation in rural towns and cities. Such alternatives might compete both with human trafficking and with conventional development projects as alternative forms of employment. Women could be offered training in organizing, supervising, and managing women workers rather than in the conventional low-level job programs, typical of international private and public sector initiatives for the poor, that offer few transferable skills. However, any job training program would have to face the corrosive poverty and marginalization of these barrios (neighborhoods) and the great power that domestic organized crime has in Colombia's underclass neighborhoods in the regions of the country where human traffickers recruit their labor.

28. In Colombia, hearings are open to the public. Tapes of hearings illustrate strategic intimidation. One example shows an apparent enforcer who enters a largely empty court room and draws attention to himself and his substantial size just as women witnesses begin to testify. 
economic crimes, such as money laundering, illicit gain, and conspiracy to commit a crime-all based on hard evidence that is much easier to establish legally.

One caveat is important to make at this juncture. This analysis has not argued that court proceedings produce uncontested "evidence" and that these "facts" unmask the constructed nature of other perspectives on human trafficking. Rather, the court room also operates in a world of representational strategies, socially mediated knowledge production, and truth claims. After all, the kinship models that judges use when they review complex testimonies and scribble their own diagrams to make sense of the flood of names and social relations, as well as the software that investigators use as they scrutinize evidence for wider patterns of kinship and subterfuge, are themselves practices in meaning making. These practices are learned informally from colleagues in the offices of the Attorney General and formally through U.S.-sponsored workshops that seek to internationally harmonize investigative methods with computer generated models that integrate data on social fields from multiple sources. This software recognizes certain kinship relations and no doubt marginalizes others. It may well inform judges' hand written annotations of case records. These cultural practices produce truths that in this instance help reveal interesting social formations involved in the business of human trafficking. ${ }^{29}$ They challenge the individualized images of predators and victims in activist accounts and dramatic antitrafficking documentaries, produced for mass entertainment on television. It is the juxtaposition of different accounts with distinctive representational strategies produced by varying interests that has been most revealing in this anthropological consideration. However, it is also important to recognize the limits to this anthropological account, given that it focuses on antitrafficking organizations, migrant labor, and the Colombian criminal justice system. This analysis is unable to deal with aspects of the human trafficking business that are out of reach, with the wealthy cosmopolitan owners of large trafficking businesses and heads of criminal networks who live abroad in global cities and enjoy impunity from prosecution. Realistically, they cannot be brought to Colombia to be prosecuted by the existing criminal justice system.

Finally, one additional sobering issue needs to be recognized. It has been virtually impossible to combat transnational human trafficking by the means we have in place-by norms and moralizing strategies that condemn it, by monitoring systems that seek to reward criminal

29. These findings come from my interviews of court officials and investigators and from national and international legal conferences for Colombian officials in the criminal justice system in 2009-2011. 
prosecutions that can be counted for national rankings, or by policing and court rooms that are nationally based but must deal with extremely fluid international networks operating in informal and illicit economies. It is the exceptionalism of sex trafficking that $I$ have tried to challenge in this analysis by asserting that more headway could be made in understanding labor trafficking by treating it as a transnational business operating in the field of family labor migration in situations of great economic inequality to generate the greatest profits for distant owners who have impunity from prosecution and to meet public demands that seem to defy regulation. 